\title{
Gas Chromatography Analysis of Diallyl Disulphide and Diallyl Trisulphide and Antioxidant Activity in Black Garlic
}

\author{
Harmita*, Herman Suryadi, Mohdar Syarif, Lidwina Deviani Liksasa \\ Faculty of Pharmacy, Universitas Indonesia, Jawa Barat, INDONESIA.
}

\begin{abstract}
Background: Diallyl disulphide (DADS) and diallyl trisulphide (DATS) found in garlic provide biological activity which protects against oxidative damage. This study aimed to confirm the presence of DADS and DATS compounds in black garlic, formed from heads of fresh garlic through a process of heating and fermentation. Methods: Analysis was performed using Shimadzu GC-17A gas chromatography with DB-5 column and flame ionisation detector at column temperatures of $140^{\circ} \mathrm{C}$ with programmed temperature rises of $1^{\circ} \mathrm{C} / \mathrm{min}$ to $180^{\circ} \mathrm{C}$, injector and detector temperatures of $200^{\circ} \mathrm{C}$ and 0.8 $\mathrm{mL} / \mathrm{min}$ flow rate. Antioxidant activity were tested against the stable DPPH (2,2-diphenyl-1-picryl-hydrazyl-hydrate) free-radical. The ability to scavenge DPPH radical was measured in these experiments by the discoloration of the solution. Results: The validation results showed that the coefficients of correlation (r) for DADS and DATS are 0.9999 in the range of $0.1-10$ $\mu \mathrm{g} / \mathrm{mL}$. The values limit of detection and limit of quantitation were 0.0096 and $0.0210 \mu \mathrm{g} / \mathrm{mL}$ for DADS compounds and 0.0198 and $0.0662 \mu \mathrm{g} / \mathrm{mL}$ for
\end{abstract}

DATS compounds. Extraction using ethyl acetate produced average content of DADS and DATS of 0.0012 and $0.0009 \%$, respectively. Conclusion: Among heating at $80^{\circ} \mathrm{C}$ and humidity of $75 \%$ for three months, it was shown that there were decreasing levels of these compounds during the ageing process from fresh garlic to black garlic and the shorter time are those that generally have a higher antioxidant activity.

Key words: Antioxidant activity, Black garlic, Diallyl disulphide, Diallyl trisulphide, Gas chromatography.

Correspondence

Prof. Dr. Harmita

Faculty of Pharmacy, Universitas Indonesia, Jawa Barat, INDONESIA.

Phone no: +62 81315148684

Email: igakadeharmita@gmail.com

DOI: 10.5530/ijpi.2020.1.4

\section{INTRODUCTION}

Garlic (Allium sativum L.) has long been used as a flavouring and also has the potential to prevent and cure various diseases. ${ }^{1}$ Garlic bulbs contains active allicin substances which have bacteriostatic and bactericidal effects in humans. ${ }^{2,3}$ The garlic commonly found in Indonesia is of the green and yellow Lumbu and Tawangmangu varieties. Green Lumbu is the superior variety, having high production potential and being recommended for planting. ${ }^{4}$ Because its water content is reduced, black garlic is lighter in weight than fresh garlic and its smell and taste are less pronounced. S-allyl cysteine in black garlic helps with absorption of allicin, enabling metabolism and making protection against bacterial infections easier to achieve. ${ }^{5}$ The results of Lee's et al.'s (2009) study showed that the Trolox equivalent antioxidant capacities of fresh and black garlic were $13.3 \pm 0.5$ and $59.2 \pm 0.8 \mu \mathrm{mol} / \mathrm{g}$, respectively, indicating that black garlic has more antioxidant activity than fresh garlic. ${ }^{6}$

The antioxidant effects of garlic are attributed to polysulphide compounds. Allicin is an organosulphur compound obtained from garlic. When fresh garlic is cut or crushed, the alliinase enzyme converts alliin to allicin, which is responsible for the scent of fresh garlic. ${ }^{7}$ Allicin is unstable and quickly changes to a series of other compounds containing sulphur, such as diallyl sulphide, diallyl disulphide (DADS) and diallyl trisulphide (DATS). Organosulphur compounds from A. sativum, such as allicin, DADS and DATS, provide powerful biological activity in protecting against oxidative damage. ${ }^{8}$ DADS and DATS are flammable liquids with a distinctive smell of garlic and are soluble in ethanol, chloroform, hexane, ethyl acetate and acetone but insoluble in water. Both of these compounds can be extracted using a liquid-liquid extraction method. Extracted allyl sulphide compounds in the form of DADS and DATS are prepared using nonpolar organic solvent in the form of hexane. ${ }^{9}$ In this study, extraction of DADS and DATS was carried out using two organic solvents and analysis of the concentration compounds was by gas chromatography with flame ionisation detector.

\section{MATERIALS AND METHODS}

\section{Instruments and materials}

Three black garlic samples, A, B and C (acquired from Total Buah Market, Indonesia) were used. Chemicals used were standard DADS and DATS (Santa-Cruz Biotechnology), 2,2-diphenyl-picrylhydrazyl (DPPH) (Sigma-Aldrich), distilled water (Ikapharmindo, Indonesia), hexane p.a., acetone p.a., acetophenone p.a. and ethyl acetate obtained from Merck and Co. USA, nitrogen gas UHP and hydrogen gas UHP. Gas chromatography GC-17A (Shimadzu, Japan) equipped with capillary column ( $30 \mathrm{~m}$ column length, $0.25 \mathrm{~mm}$ inner diameter size, $0.25 \mu \mathrm{m}$ thickness film with HP stationary phase-1) and flame ionisation detector using helium as the carrier gas. Pulsed splitless injections (1:20) were performed at an initial pressure of $40 \mathrm{psi}$ and $200^{\circ} \mathrm{C}$, returning to $10 \mathrm{psi}$ at $1 \mathrm{~min}$ and followed by an injector purge. The initial oven temperature was $180^{\circ} \mathrm{C}$ for $1 \mathrm{~min}$, ramped at $1^{\circ} \mathrm{C} \mathrm{min}^{-1}$ to $180^{\circ}$.

\section{Preparation of diallyl disulphide and diallyl trisulphide standard mixture solution}

DADS and DATS were measured precisely for $10 \mathrm{mg}$, put into $20.0 \mathrm{~mL}$ volumetric flasks and dissolved with acetone to the limit of the volumetric flask, $20 \mu \mathrm{g} / \mathrm{mL}$ standard solution therefore being obtained.

\section{Determination of optimum analysis}

$1.0 \mathrm{~mL}$ samples of DADS and DATS standard mixture solvents at $20 \mu \mathrm{g} /$ $\mathrm{mL}$ were pipetted, added to $2.0 \mathrm{~mL}$ acetophenone and shaken in a vortex 
until homogenous. The solutions were injected into the gas chromatograph in volumes of $1.0 \mu \mathrm{L}$. The determination of optimum analysis was conducted by temperature programmes at initial temperature variations of 130,140 and $150^{\circ} \mathrm{C}$ and flow rate variations of $0.8,1.0$ and $1.2 \mathrm{~mL} /$ min. Initial temperature was raised $1^{\circ} \mathrm{C} / \mathrm{min}$ to $180^{\circ} \mathrm{C}$ and injector and detector temperatures were set at $200^{\circ} \mathrm{C}$. Retention time, tailing factor, the number of theoretical plates, height equivalent to the theoretical plates (HETP) and resolution of each condition were recorded.

\section{System suitability test}

$1.0 \mathrm{~mL}$ samples of DADS and DATS standard mixture solvent at $20 \mu \mathrm{g} /$ $\mathrm{mL}$ were pipetted, added to $2.0 \mathrm{~mL}$ acetophenone and shaken in a vortex until homogenous. The solutions were injected into the gas chromatograph in $1.0 \mu \mathrm{L}$ volumes. System suitability testing was conducted six times and the results were recorded and calculated for coefficient variation.

\section{Validation methods}

\section{Selectivity test}

$1.0 \mathrm{~mL}$ samples of DADS and DATS standard mixture solvent with 20 $\mu \mathrm{g} / \mathrm{mL}$ concentration were pipetted, added to $2.0 \mathrm{~mL}$ acetophenone and shaken using a vortex until homogenous. The solutions were injected into the gas chromatograph in $1.0 \mu \mathrm{L}$ volumes. Matrix blank solution was injected with the same volume and the chromatogram was observed to assess whether there was a disturbance of the retention time of DADS and DATS from the matrix component.

\section{Calibration curve and linearity test}

The solutions of DADS and DATS standard were diluted using acetone solvent to the limitation mark and homogenised. Final concentrations were obtained at $0.1,1,3,5,7$ and $10 \mu \mathrm{g} / \mathrm{mL}$.

For each solution, $0.2 \mathrm{~mL}$ acetophenone was added and shaken until homogenised. The solutions were injected into the gas chromatograph with selected analysis conditions in $1.0 \mu \mathrm{L}$ samples. The calibration curve was drawn up between peak area as the $y$ axis and injected concentration as the $x$ axis and linear regression equations and correlation coefficients were calculated.

\section{Limit of detection and limit of quantitation tests}

Limit of detection (LOD) and limit of quantity (LOQ) can be determined though linear regression line equations from the calibration curve. LOD and LOQ were calculated by measuring blank response several times and the standard blank deviation was calculated. Standard blank deviation was the same as standard residual deviation.

\section{Accuracy and precision test}

For this, the addition method was performed by adding the number of analytes with certain concentrations into observed samples. For recovery testing, four $250 \mu \mathrm{L}$ samples of solutions were pipetted into $1.0 \mathrm{~mL}$ volumetric flasks. Standard solution was added with three different concentrations $(80,100$ and $120 \%)$ to each volumetric flask.

\section{The selection of appropriate extraction solvent}

A sample of $10 \mathrm{~g}$ of peeled and mashed garlic was put into a $100 \mathrm{~mL}$ Erlenmeyer flask, covered with plastic and allowed to rest for $30 \mathrm{~min}$. Then $30 \mathrm{~mL}$ of distilled water was added and the flask was re-covered. The flask was heated in a boiling water bath for $10 \mathrm{~min}$ and allowed to cool. After cooling, $30 \mathrm{~mL}$ of hexane solvent was added and it was again covered. The flask was shaken at $150 \mathrm{rpm}$ at room temperature for $12 \mathrm{hr}$ and then stored at room temperature for six days.
The organic layer was separated and stored in a freezer at $-20^{\circ} \mathrm{C}$ to separate the remaining water by freezing. The solvent in the extraction was evaporated using a rotary evaporator at $40^{\circ} \mathrm{C}$ to produce a yellowish, strong-smelling oil. The oil was then dissolved with acetone until it reached $500 \mu \mathrm{L}, 100 \mu \mathrm{L}$ acetophenone was added and the mixture was shaken in a vortex until homogenous. The sample solution was filtered using a PVDF $0.45 \mu \mathrm{m}$ syringe filter and $1.0 \mu \mathrm{L}$ was injected into the gas chromatogram. These steps were repeated using ethyl acetate and results obtained with hexane and ethyl acetate solvents were compared.

\section{Extraction with selected solvent}

Black garlic was peeled and mashed and $6.5 \mathrm{~g}$ samples, were put into a $100 \mathrm{ml}$ Erlenmeyer flask which was covered with plastic. It was rested for $30 \mathrm{~min}, 30 \mathrm{~mL}$ distilled water was added and it was covered again. The flask was heated in a boiling water bath for $10 \mathrm{~min}$ and allowed to cool. After cooling, $30 \mathrm{~mL}$ ethyl acetate solvent was added and it was covered again. It was shaken at $150 \mathrm{rpm}$ at room temperature for $12 \mathrm{hr}$ and then stored at room temperature for six days. The organic layer was separated and stored in a freezer at $-20^{\circ} \mathrm{C}$ to separate the remaining water by freezing. The solvent in the extraction was evaporated using a rotary evaporator at $40^{\circ} \mathrm{C}$ to produce a yellowish strong-smelling oil.

\section{Analysis of diallyl disulphide and diallyl trisulphide}

The oil sample was diluted to $500 \mu \mathrm{L}$ using acetone and then $100 \mu \mathrm{L}$ acetophenone was added. The sample solution was filtered using a PVDF $0.45 \mu \mathrm{m}$ filter and $1 \mu \mathrm{L}$ of sample solution was injected into the gas chromatograph. Retention time was recorded and compared to standard retention time. The obtained comparison data was used as a basic identification of DADS and DATS for qualitative analysis. Black garlic sample levels were measured based on each compound's linear regression equation for quantitative analysis of black garlic samples made by heating at $80^{\circ} \mathrm{C}$ and humidity $75 \%$ for $0,1,2$ and 3 months.

\section{Antioxidant activity}

The DPPH test was carried out as described before. ${ }^{6,10}$ The supernatant $(1 \mathrm{~mL})$ of the samples and its active main compounds were mixed with 5 $\mathrm{mL}$ of a $0.004 \%$ methanol solution of DPPH. After an incubation period of $30 \mathrm{~min}$, the absorbance of the samples was read at $517 \mathrm{~nm}$ using a Shimadzu UV-1240 spectrophotometer, ascorbic acid were used as positive controls

\section{RESULTS}

\section{Determination of optimum analysis condition}

Determination of optimum analysis condition was conducted using a temperature programme with variation of initial temperatures of 130 , 140 and $150^{\circ} \mathrm{C}$ and carrier gas flow rates of $0.8,1.0$ and $1.2 \mathrm{~mL} / \mathrm{min}$. The initial temperatures were increased at $1^{\circ} \mathrm{C} / \mathrm{min}$ to $180^{\circ} \mathrm{C}$ and the injector and detector temperatures were set at $200^{\circ} \mathrm{C}$. In this experiment, the analysis condition for optimum DADS and DATS mixture was found to be at initial column temperature of $140^{\circ} \mathrm{C}$ with $1^{\circ} \mathrm{C} / \mathrm{min}$ increase to $180^{\circ} \mathrm{C}$, injector and detector temperatures of $200^{\circ} \mathrm{C}$ and $0.8 \mathrm{~mL} / \mathrm{min}$ carrier gas flow rate. The chromatograph results showed large DADS and DATS peak areas of 288,670 and 67,905 , respectively. The retention time was neither too fast nor too slow, at $5.963 \mathrm{~min}$ for DADS and 12.27 min for DATS. The smallest HETP values were $0.0916 \mathrm{~cm}$ (DADS) and $0.0637 \mathrm{~cm}$ (DATS). The theoretical plate values (N) were 3271.479 plates (DADS) and 47,069.792 plates (DATS). The tailing factors were 0.626 (DADS) and 0.748 (DATS). The resolution factors for DADS and DATS compounds were 35.32 , showing good separation. Results are shown in Figure 1. 


\section{System suitability test}

The system-suitability test was obtained from six iterations of standard DADS and DATS mixture solution injection results. The variation coefficient values for DADS and DATS compounds were 1.6388 and $0.4531 \%$, respectively.

\section{Validation methods}

\section{Selectivity test}

Selectivity testing was performed by injecting used blank sample or solvent without any DADS and DATS compounds to see the disturbance of any other chromatograph peaks around retention times from DADS and DATS compounds.

\section{Calibration curve and linearity test}

Linear regression calculation results applied to the calibration curve found that the calibration curve line equation for DADS was $y=$ $13068.97 x-3373.62$ and for DATS was $y=3194.39 x-307.22$. The result of linearity testing of DADS and DATS in the standard solution was 0.9999 for both. The results could therefore be stated as being valid because they met linearity criteria by obtaining correlation coefficients close to 1 or $\geq 0.9990$.

\section{Limit of detection and limit of quantitation tests}

Based on the results of linear regression equations, LOD and quantity value were calculated for each compound statistically. For DADS compounds, the LOD value was $0.0096 \mu \mathrm{g} / \mathrm{mL}$ and the LOQ value was $0.0210 \mu \mathrm{g} / \mathrm{mL}$. For DATS compounds, the LOD and LOQ values were 0.0198 and $0.0662 \mu \mathrm{g} / \mathrm{mL}$, respectively.

\section{Accuracy and precision test}

The accuracy criterion is met if percentage recovery (\% UPK) is between 98 and $102 \%$. For the DADS and DATS compounds, each concentrate at the six iterations gave recovery values of between 98.05 and $101.76 \%$. The precision criterion is achieved if the method gives relative standard deviation or variation coefficient of no more than $2 \%$. The results gave coefficient values of 0.58 to $1.50 \%$.

\section{The determination of extraction solvent}

The determination of extraction for the solvents hexane and ethyl acetate are shown in Table 1. The results show that ethyl acetate could extract DADS and DATS better than hexane, so ethyl acetate would be used for the next extraction.

\section{Analysis of diallyl disulphide and diallyl trisulphide}

Qualitative analyses of DADS and DATS determinations are shown in Figure 2-4. In sample A there was DADS and DATS with retention times of 5,987 and 12,228 min, respectively. In sample B there was DATS with a retention time of $12,348 \mathrm{~min}$. In sample $\mathrm{B}$ no trace of DADS was found. In sample $\mathrm{C}$ there are DADS and DATS with retention times of 5,838 and 12,088 min. Tables 2 and 3 indicate levels of DADS and DATS in samples A, B and C. Average levels of DADS and DATS in sample A were 0.0012 and $0.0010 \%$, respectively, while sample $C$ had average levels of 0.0007 and $0.0013 \%$. DADS and DATS were not detected in sample B because the results did not include LOD.

Tables 4 and 5 provide data of determination of DADS and DATS levels in black garlic samples made by heating at $80^{\circ} \mathrm{C}$ and humidity $75 \%$ for 1 to 3 months. The average of DADS compounds obtained from 1-, 2- and 3-month black garlic extracts were 0.0021, 0.0020 and $0.0014 \%$, respectively. The average of DATS compounds obtained from 1-, 2- and

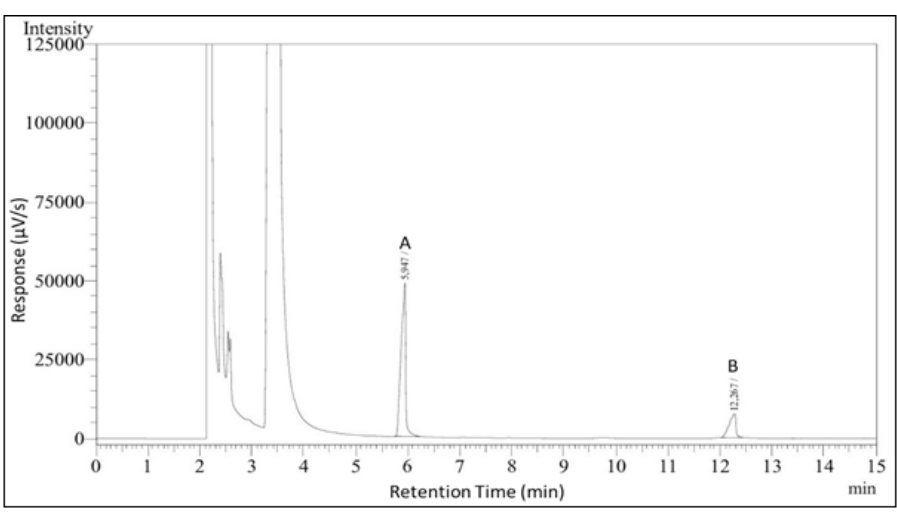

Figure 1: Chromatograph of standard DADS (A) and DATS (B) with initial column temperature $140^{\circ} \mathrm{C}$ and carrier gas flow rate $0.8 \mathrm{~mL} / \mathrm{min}$.

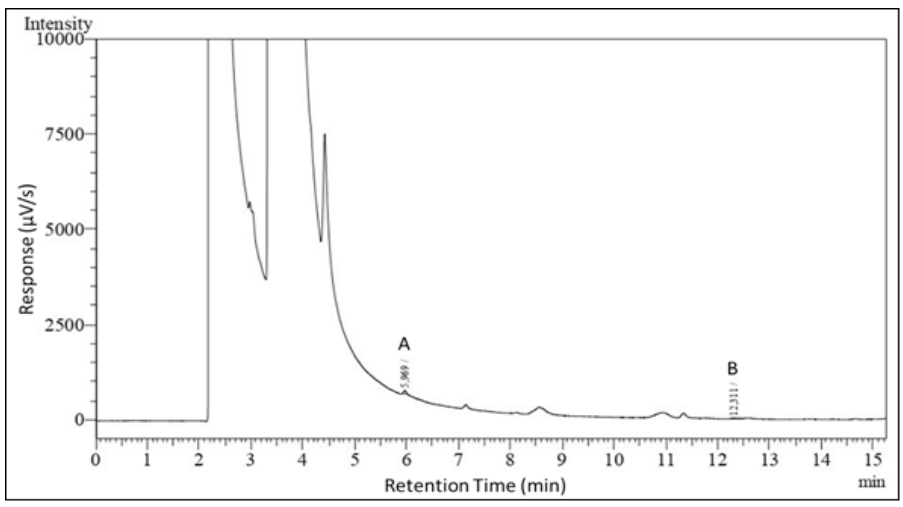

Figure 2: Chromatograph of DADS (A) and DATS (B) in sample A.

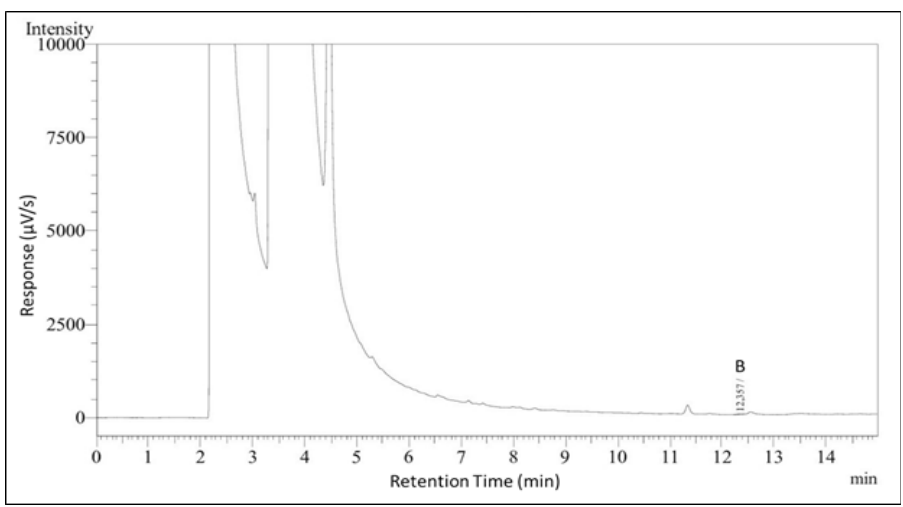

Figure 3: Chromatograph of DADS (A) and DATS (B) in sample B.

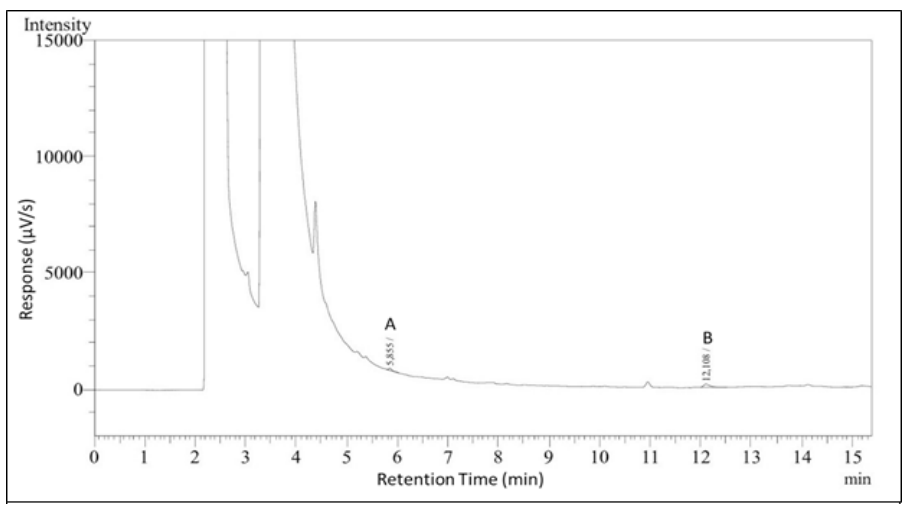

Figure 4: Chromatograph of DADS (A) and DATS (B) in sample C. 
Table 1: The determination of extraction solvent of DADS and DATS compound data.

\begin{tabular}{|c|c|c|c|c|c|c|c|c|c|c|c|c|}
\hline \multirow[t]{2}{*}{ Solvent } & \multicolumn{2}{|c|}{$\begin{array}{l}\text { Extract weight } \\
\text { obtained } \\
\text { (gram) }\end{array}$} & \multicolumn{2}{|c|}{$\begin{array}{l}\text { Retention Time } \\
\text { (minutes) }\end{array}$} & \multicolumn{2}{|c|}{ Peak Area $(\mu \mathrm{V} / \mathrm{s})$} & \multicolumn{2}{|c|}{$\begin{array}{c}\text { Measured } \\
\text { Concentration }(\mu \mathrm{g} / \\
\mathrm{mL})\end{array}$} & \multicolumn{2}{|c|}{ Concentration (\%) } & \multicolumn{2}{|c|}{$\begin{array}{c}\text { Average } \\
\text { Concentration (\%) }\end{array}$} \\
\hline & DADS & DATS & DADS & DATS & DADS & DATS & DADS & DATS & DADS & DATS & DADS & DATS \\
\hline \multirow{3}{*}{ Hexane } & \multirow{3}{*}{0.00985} & \multirow{3}{*}{0.00985} & 5.932 & 12.203 & 67296 & 4368 & 5.4074 & 1.4635 & 0.0275 & 0.0074 & \multirow{3}{*}{$\begin{array}{c}0.0279 \\
\pm 0.0004\end{array}$} & \multirow{3}{*}{$\begin{array}{c}0.0075 \\
\pm 0.0002\end{array}$} \\
\hline & & & 5.895 & 12.160 & 69825 & 4422 & 5.6009 & 1.4804 & 0.0284 & 00075 & & \\
\hline & & & 5.914 & 12.194 & 68311 & 4427 & 5.4851 & 1.4820 & 0.0278 & 0.0075 & & \\
\hline \multirow{3}{*}{$\begin{array}{c}\text { Ethyl } \\
\text { Acetate }\end{array}$} & \multirow{3}{*}{0.01034} & \multirow{3}{*}{0.01034} & 5.958 & 12.210 & 107240 & 4826 & 5.4074 & 1.6069 & 0.0409 & 0.0077 & \multirow{3}{*}{$\begin{array}{c}0.0417 \\
\pm 0.0008\end{array}$} & \multirow{3}{*}{$\begin{array}{c}0.0078 \\
\pm 0.0004\end{array}$} \\
\hline & & & 5.940 & 12.179 & 111531 & 4903 & 56009 & 1.6310 & 0.0425 & 0.0079 & & \\
\hline & & & 5.962 & 12.224 & 109243 & 4782 & 5.4851 & 1.5931 & 0.0417 & 0.0077 & & \\
\hline
\end{tabular}

Table 2: Data results of diallyl disulfide (DADS) concentration in samples.

\begin{tabular}{|c|c|c|c|c|c|}
\hline Samples & $\begin{array}{l}\text { Extract Weight Obtained } \\
\qquad(\text { Gram) }\end{array}$ & $\begin{array}{l}\text { Peak Area Analysis Results } \\
\qquad(\mu \mathrm{V} / \mathrm{s})\end{array}$ & $\begin{array}{l}\text { Amount of Measured } \\
\text { Concentration } \\
(\mu \mathrm{g} / \mathrm{mL})\end{array}$ & $\begin{array}{c}\text { Concentration } \\
(\%)\end{array}$ & $\begin{array}{c}\text { Average } \\
\text { Concentration } \\
(\%)\end{array}$ \\
\hline \multirow{4}{*}{ A } & \multirow{2}{*}{0.01424} & 1151 & 0.3462 & 0.0012 & \multirow[b]{3}{*}{$0.0012 \pm 0.00$} \\
\hline & & 1145 & 0.3457 & 0.0012 & \\
\hline & \multirow{2}{*}{ 0.W01449 } & 1142 & 0.3455 & 0.0012 & \\
\hline & & 1147 & 0.3459 & 0.0012 & \multirow{3}{*}{ Not detected } \\
\hline \multirow{2}{*}{ B } & 0.01508 & - & - & - & \\
\hline & 0.01457 & - & - & - & \\
\hline \multirow{4}{*}{$\mathrm{C}$} & \multirow{2}{*}{0,02119} & 376 & 0.2869 & 0.0007 & \multirow{4}{*}{$0.0007 \pm 0.00$} \\
\hline & & 378 & 0.2870 & 0.0007 & \\
\hline & \multirow[t]{2}{*}{0,01969} & 372 & 0.2866 & 0.0007 & \\
\hline & & 375 & 0.2868 & 0.0007 & \\
\hline
\end{tabular}

Table 3: Data results of diallyl trisulfide (DATS) concentration in samples.

\begin{tabular}{|c|c|c|c|c|c|}
\hline Samples & $\begin{array}{l}\text { Extract Weight } \\
\text { Obtained (Gram) }\end{array}$ & $\begin{array}{l}\text { Peak Area Analysis Results } \\
\qquad(\mu \mathrm{V} / \mathrm{s})\end{array}$ & $\begin{array}{l}\text { Amount of Measured } \\
\text { Concentration } \\
(\mu \mathrm{g} / \mathrm{mL})\end{array}$ & $\begin{array}{l}\text { Concentration } \\
\text { (\%) }\end{array}$ & $\begin{array}{c}\text { Average } \\
\text { Concentration } \\
\text { (\%) }\end{array}$ \\
\hline \multirow{4}{*}{ A } & \multirow{2}{*}{0.01424} & 585 & 0.2793 & 0.0010 & \multirow{4}{*}{$0.0010 \pm 0.00$} \\
\hline & & 581 & 0.2780 & 0.0010 & \\
\hline & \multirow{2}{*}{0.01449} & 583 & 0.2786 & 0.0010 & \\
\hline & & 587 & 0.2799 & 0.0010 & \\
\hline \multirow[b]{2}{*}{ B } & 0.01508 & - & - & - & \multirow[t]{2}{*}{ Not detected } \\
\hline & 0.01457 & - & - & - & \\
\hline \multirow{4}{*}{$\mathrm{C}$} & 002110 & 1428 & 0.5432 & 0.0013 & \multirow{4}{*}{$0.0013 \pm 0.00$} \\
\hline & \multirow{3}{*}{0.01969} & 1420 & 0.5407 & 0.0013 & \\
\hline & & 1439 & 0.5466 & 0.0013 & \\
\hline & & 1433 & 0.5447 & 0.0013 & \\
\hline
\end{tabular}


Table 4: Data results of diallyl disulfide (DADS) levels in samples $A$ by heating at $80^{\circ} \mathrm{C}$ and humidity $75 \%$ for 3 months.

\begin{tabular}{|c|c|c|c|c|c|}
\hline Month & $\begin{array}{l}\text { Weight of extraction } \\
\text { (gram) }\end{array}$ & $\begin{array}{l}\text { Areas } \\
(\mu \mathrm{V} / \mathrm{s})\end{array}$ & $\begin{array}{l}\text { Measured value } \\
\qquad(\mu \mathrm{g} / \mathrm{mL})\end{array}$ & Concentration (\%) & $\begin{array}{c}\text { Average concentration } \\
(\%)\end{array}$ \\
\hline \multirow{3}{*}{1} & 0.01482 & 4926 & 0.6351 & 0.0021 & \multirow{3}{*}{$0.0021 \pm 0.00$} \\
\hline & \multirow{2}{*}{0.01474} & 4740 & 0.6208 & 0.0021 & \\
\hline & & 4861 & 0.6301 & 0.0021 & \\
\hline \multirow{2}{*}{2} & \multirow{2}{*}{0.01897} & 6205 & 0.7329 & 0.0019 & \multirow{2}{*}{$0.0020 \pm 0.00006$} \\
\hline & & 6176 & 0.7307 & 0.0019 & \\
\hline \multirow{2}{*}{3} & \multirow{2}{*}{0.01913} & 3666 & 0.5386 & 0.0014 & \multirow{2}{*}{$0.0014 \pm 00005$} \\
\hline & & 3660 & 0.5382 & 0.0014 & \\
\hline
\end{tabular}

Table 5: Data results of diallyl trisulfide (DATS) levels in samples $\mathrm{A}$ by heating at $80^{\circ} \mathrm{C}$ and humidity $75 \%$ for 3 months.

\begin{tabular}{|c|c|c|c|c|c|}
\hline Month & Weight of extraction (gram) & $\begin{array}{l}\text { Areas } \\
(\mu \mathrm{V} / \mathrm{s})\end{array}$ & $\begin{array}{l}\text { Measured value } \\
\qquad(\mu \mathrm{g} / \mathrm{mL})\end{array}$ & Concentration (\%) & $\begin{array}{c}\text { Average concentration } \\
(\%)\end{array}$ \\
\hline \multirow{4}{*}{1} & \multirow{2}{*}{0,01482} & 3942 & 1.3302 & 0.0045 & \multirow{4}{*}{$0.0044 \pm 0.00008$} \\
\hline & & 4058 & 1.3665 & 0.0046 & \\
\hline & \multirow{2}{*}{0.01474} & 3737 & 1.2660 & 0.0043 & \\
\hline & & 3763 & 1.2743 & 0.0043 & \\
\hline \multirow{4}{*}{2} & \multirow{2}{*}{0.01903} & 3034 & 1.0460 & 0.0027 & \multirow{4}{*}{$0.0027 \pm 0.00005$} \\
\hline & & 3061 & 1.0544 & 0.0028 & \\
\hline & \multirow{2}{*}{0.01897} & 2865 & 0.9931 & 0.0026 & \\
\hline & & 2847 & 0.9874 & 0.0026 & \\
\hline \multirow{4}{*}{3} & \multirow{2}{*}{0.01913} & 2095 & 0.7520 & 0.0019 & \multirow{4}{*}{$0.0020 \pm 0.00006$} \\
\hline & & 2126 & 0.7617 & 0.0020 & \\
\hline & \multirow{2}{*}{0.01887} & 2086 & 0.7493 & 0.0020 & \\
\hline & & 2011 & 0.7257 & 0.0019 & \\
\hline
\end{tabular}

Table 6: Effect of the test compounds in the DPPH assay.

\begin{tabular}{cc}
\hline Compounds & $\mathrm{IC}_{50}(\mathrm{mg} / \mathrm{mL})$ \\
\hline Sample A (1 month) & $28.8 \pm 1.22$ \\
Sample A (2 month) & $35.3 \pm 6.31$ \\
Sample A (3 month) & $114.7 \pm 1.24$ \\
Diallyl disulfide (DADS) & $74.9 \pm 3.43$ \\
Diallyl Trisulfide (DATS) & $79.7 \pm 0.93$ \\
Acid ascorbic & $2.2 \pm 2.43$ \\
\hline
\end{tabular}

3-month black garlic extracts were $0.0044 \%, 0.0027 \%$ and $0.0020 \%$ respectively.

\section{Antioxidant activity}

In the DPPH test the ability of a compound to act as donor for hydrogen atoms or electrons was measured spectrophotometrically. Both black garlic samples that are in 1 to 3 months as well as oils and pure compounds are able reducing stable DPPH radicals to yellow diphenylpic- rylhydrazine. The strongest effect was demonstrated by samples stored for 1 month with $\mathrm{IC}_{50}$ of $28.8 \mathrm{mg} / \mathrm{mL}$. The results are shown in Table 6.

\section{DISCUSSION}

In this research, optimum analysis conditions needed to be identified to assess the best conditions for analysis of DADS and DATS. Such conditions would give relatively short retention time and good separation in order to enable good results analysis. Temperature of injector should be set higher than that of column in order that all samples could be immediately evaporated shortly after injection. The results were then managed so that optimum condition could be determined for analysing DADS and DATS. Short retention time, large peak area, large numbers of theoretical plates, small column efficiency, small tailing factor $\left(\mathrm{T}_{f}\right)$ and good separation are all considered in determining optimum condition. ${ }^{11}$ In this experiment, all parameters fulfilled the optimum condition criteria with small HETP values, more than 3000 theoretical plates, tailing factors of below 1.0 and resolution of more than 1.5.11,12 The retention time of this research was quite precise in comparison to research conducted by Lim et al. (2014), in which the retention times of DADS and DATS were 15.6 and $18.3 \mathrm{~min}$, respectively. Too fast a retention time would cause a 
chromatograph peak for DADS compounds too close to the solvent peak, thus distracting from the obtained peak area result, while if the retention time was too long the analysis process would be lengthened. The addition of acetophenone in the determination process sharpened the peaks for DADS and DATS.

The optimum analysis condition determined had to be initially systemsuitability tested to ensure the effectiveness of the operational system in regard to possible variations in equipment used and analysis techniques. Based on data, the results met the coefficient variation requirement or repetition value of $\leq 2 \%{ }^{13}$

To evaluate the proposed analytical gas chromatography method, we assessed its selectivity, linearity, LOD, LOQ, precision and accuracy. The selectivity test was the chromatograph result of the blank sample which showed that there was no other peak around the retention times of DADS and DATS, thus allowing us to state that the method was selective. The calibration curves for DADS and DATS had correlation coefficients for all compounds exceeding 0.9999 , indicating the high utility of this method. ${ }^{14}$

The LOD is the lowest concentration of an analyte in a sample that can be detected, but not quantitated, while LOQ is the lowest concentration of an analyte in a sample that can be determined with an acceptable precision and accuracy under the conditions of the method. ${ }^{12}$ The LOD and LOQ for this method were determined as $\sigma / \mathrm{s}$ ratios of 3.3 and 10 , respectively, where $\sigma$ and $s$ represent the standard deviation of the y-intercepts obtained using regression analysis and the slope of the calibration curve, respectively). ${ }^{14}$ Overall, the results confirm that the developed analytical method is adequate for the detection and quantification of DADS and DATS.

Evaluation of accuracy shows the degree of closeness of analysis results and real analyte levels. Accuracy is expressed as the percentage recovery of the analyte added. Data obtained from six replicas had recovery values of between 98.05 and $101.76 \%$, indicating that they met the accuracy criterion. To assess the precision of the method, intra- and inter-day tests were performed. Precision measures the degree of repeatability of an analytical method performed under normal conditions. This value is normally expressed as the percentage of relative standard deviation. The precision based on an intra-day test was evaluated using replicate measurements with standard solutions at three different concentration levels. The relative standard deviation was 0.58 to $1.50 \%$, indicating good repeatability and reproducibility. ${ }^{15}$

Black garlic extraction was conducted using a slight modification of the extraction method used by Tocmo et al. (2017) The solvent used for extraction should have low solubility, lower boiling point than the compound and be able to extract DADS and DATS. The solvents used for comparison were hexane and ethyl acetate, because both met the criteria. The weight of ethyl acetate extract was 0.01034 which was higher than hexane at $0.00985 \mathrm{~g}$. The result of obtained average calculations for DADS compound were 0.0417 (ethyl acetate) and $0.0279 \%$ (hexane), while the calculations of average levels obtained from DATS were 0.0078 (ethyl acetate) and $0.0075 \%$ (hexane). The results showed that ethyl acetate solvent could extract DADS and DATS more effectively than hexane, so ethyl acetate would be used for the next extraction..$^{9,10,16}$

Qualitative analysis was carried out by comparing the results of the sample chromatogram with the results of a standard chromatogram mixture of DADS and DATS. DADS and DATS were present in sample A with a retention time of 5,987 and 12,228 min, respectively. Sample B contained DATS with a retention time of $12,348 \mathrm{~min}$. In sample $\mathrm{B}$ no trace of DADS was found. DADS and DATS were detected in sample $\mathrm{C}$ with retention times of 5,838 and 12,088 min. Diallyl sulphides were the major components of the extract, followed by the allyl methyl and dimethyl sulphide series. ${ }^{17,18}$ DADS and DATS levels in A, B and C samples of black garlic extracted using ethyl acetate solvent were calculated based on linear regression equations. The average levels of DADS and DATS in sample A were 0.0012 and $0.0010 \%$, respectively. They were not detected in sample $\mathrm{B}$ because the results did not achieve LOD and in sample C were 0.0007 and $0.0013 \%$, respectively. Based on these results, the highest levels of DADS was obtained from sample A, at $0.0012 \%$ and the highest levels of DATS was obtained from sample C, at $0.0013 \%$.

The results showed the DADS and DATS compound contents of samples produced by heating garlic at $80^{\circ} \mathrm{C}$ and humidity of $75 \%$ for 1,2 and 3 months. The retention times of DADS and DATS in the 1-month black garlic sample were 6.017 and $12.383 \mathrm{~min}$, respectively. For the 2-month black garlic sample, DADS and DATS had retention times of 6.007 and 12.37 min, respectively. For the 3-month black garlic sample DADS and DATS had retention times of 6.053 and 12.458 min, respectively. Quantitative levels in fresh garlic were quite high and significantly decreased in the process of converting it into black garlic. During the ageing process over 1, 2 and 3 months the DADS and DATS content continued to decrease. DADS and DATS are responsible for the strong flavour and smell of garlic. Black garlic does not have the strong flavour and smell of fresh garlic because DADS and DATS contents have decreased during the ageing process. ${ }^{19}$ Allicin is the main and characteristic flavour substance in fresh garlic and in black garlic, the strong odour of fresh garlic has been removed. ${ }^{20}$ The allicin content rapidly decreases at the early stage of thermal processing and its decrease rate was slightly discrepant. These results suggest that black garlic hardly had any strong odour and allicin was no longer a significant functional substance. ${ }^{21}$

In a series of in vitro tests the compounds exhibited antioxidant activity. It acted as a donating agent in the DPPH assay and possessed hydroxyl radical scavenging properties in both the assay for non-enzymatic lipid peroxidation and the deoxyribose test. ${ }^{10}$ In this study using the free radical scavenging capacity (RCS) method, the RSC method measures the antioxidant activity of the sample by evaluating the ability of the sample to capture the free radical DPPH. The DPPH radical is one of the most commonly used substrates for the evaluation of antioxidant activity because of its stability (radically form) and the simplicity of the test. ${ }^{5}$ The free radical scavenging activity of phenol compounds is influenced by the amount and position of phenolic hydrogen in the molecule. The higher the number of hydroxyl groups possessed by phenol compounds, the higher the antioxidant activity produced. ${ }^{22}$ Furthermore, in this study, sample A heated at $80^{\circ} \mathrm{C}$ and humidity of $75 \%$ for three months show a value of antioxidant activity $\left(\mathrm{IC}_{50}\right)$ in the range of a $28.8-114.7 \mathrm{mg} / \mathrm{mL}$. It means that based on the classification of the value of antioxidant activity of $10 \mathrm{mg} / \mathrm{ml},<\mathrm{IC}_{50}<30 \mathrm{mg} / \mathrm{mL}$ is included in the criteria proof that antioxidants activity exists. ${ }^{5}$

\section{CONCLUSION}

The optimum solvent for extracting DADS and DATS from black garlic by liquid-liquid extraction was ethyl acetate. Sample A showed that by heating at $80^{\circ} \mathrm{C}$ and humidity of $75 \%$ for 3 months there were decreasing levels of DADS and DATS during the ageing process from fresh garlic to black garlic and the shorter time ( 1 and 2 months) are those that generally have a higher antioxidant activity

\section{ACKNOWLEDGEMENT}

This work was supported by the Directorate of Research and Community Service (DRPM) Universitas Indonesia with grand number NKB-0197/ UN2.R3.1/HKP.05.00/2019.

\section{CONFLICT OF INTEREST}

The authors declare no conflict of interest. 


\section{ABBREVIATIONS}

DADS: Diallyl disulphide; DATS: Diallyl trisulphide; LOD: Limit of detection, LOQ: Limit of quantitation; DPPH: 2,2-diphenyl-1-picrylhydrazyl-hydrate; HETP: Height equivalent to the theoretical plates; RCS: Radical scavenging capacity.

\section{REFERENCES}

1. Amagase $H$. Clarifying the real bioactive constituents of garlic. J Nutr. 2016;136(3):716S-25S

2. Ho CY, Cheng Y, Chau CF, Yen GC. Effect of diallyl sulfide on in vitro and in vivo Nrf2-Mediated pulmonic antioxidant enzyme expression via activation ERK/p38 signaling pathway. J Agricul Food Chem. 2011;60(1):100-7.

3. Ha AW, Ying T, Kim WK. The effects of black garlic (Allium satvium) extracts on lipid metabolism in rats fed a high fat diet. Nutri Res Pract. 2015:9(1):30-6.

4. Rukmana R. Budidaya Bawang Putih. Yogyakarta, Indonesia: Kanisius Press 2012. Retrieved from https://books.google.co.id/books/about/Budi_Daya_Bawang_Putih.html?id=u_Cyl5HqQKUC\&redir_esc $=y$

5. Kimura S, Tung YC, Pan MH, Su NW, Lai YJ, Cheng KC. Black garlic: A critical review of its production, bioactivity and application. J Food Drug Anal. 2017;25(1):62-70.

6. Lee YM, Gweon OC, Seo YJ, Im J, Kang MJ, Kim MJ, et al. Antioxidant effect of garlic and aged black garlic in animal model of type 2 diabetes mellitus. Nutr Res Pract. 2009;3(2):156-62.

7. Block E. Garlic and Other Alliums: The Lore and the Science. New York: RSC Publishing. 2010;78-81.

8. Borlinghaus J, Albrecht F, Gruhlke MC, Nwachukwu ID, Slusarenko AJ. Allicin: Chemistry and biological properties. Molecules. 2014;19(8):12591-618.

9. Tocmo R, Wu Y, Liang D, Fogliano V, Huang D. Boiling enriches the linear polysulfides and the hydrogen sulfide-releasing activity of garlic. Food Chem. 2017:221:1867-73

10. Lim S, Lee J, Kim J, Choi G, Cho N, Park B. Determination of dimethyl disulfide diallyl disulfide and diallyl trisulfide in biopesticides containing Allium sativum extract by gas chromatography. Korean J Environ Agri. 2014;33(4):381-7.

11. Watson CJ, Souza D, Silva C, Tull D, Garland SM, Lawson LD. Attempt to detect garlic allyl sulphides from saliva after consumption of garlic tablets using GC MS. J Micro Biochem Tech. 2013;5:81-3.

12. Martins N, Petropoulos S, Ferreira IC. Chemical composition and bioactive compounds of garlic (Allium sativum L.) as affected by pre- and post-harvest conditions: A review. Food Chem. 2016;211:41-50.

13. Kim S, Lee S, Shin D, Yoo M. Validation of a high-performance liquid chromatography photo-diode array method for the temperature effects on Alk(En)y sulfides in garlic extracts. J Liq Chrom Related Tech. 2015;38(17):1608-15.

14. Lee SN, Kim NS, Lee DS. Comparative study of extraction techniques for deter mination of garlic flavor components by gas chromatography-mass spectrometry. Anal Bioanal Chem Res. 2003;377(4):749-56.

15. Jang $\mathrm{H}$, Lee $\mathrm{H}$, Yoon DK, Ji DS, Kim JH, Lee CH. Antioxidant and antimicrobial activities of fresh garlic and aged garlic by-products extracted with different solvents. Food Sci Biotechnol. 2017:27(1):219-25.

16. Tsai $\mathrm{C}$, Chen H, Sheen L, Lili C. Garlic: Health benefits and actions. Biomedicine. 2012;2(1):17-29.

17. Rose P, Whiteman M, Moore PK, Zhu YZ. Bioactive S-alk(en)yl cysteine sulfoxide metabolites in the genus Allium: The chemistry of potential therapeutic agents. Nat Prod Rep. 2005;22(3):351-68.

18. Shin JH, Choi DJ, Lee SJ, Cha JY, Kim JG, Sung NJ. Change of physicochemical components and antioxidant activity of garlic during its processing. J Life Sci. 2008;18(18):1123-31.

19. Song $K$, Milner JA. The influence of heating on the anticancer properties of garlic. J Nutr. 2001;131(3s):1054S-7S.

20. Mohseni M, Azarmi Y, Babaei H, Eghbal M, Fathi-Azad F. Inhibitory effect of garlic (Alliun sativum) juice on nitroglycerin-induced vasorelaxation tolerance in rat isolated thoracic aorta. Res Pharm Sci. 2012;7(5):S840.

21. Zhang X, Li N, Lu X, Liu P, Qiao X. Effects of temperature on the quality of black garlic. J Sci Food Agri. 2016;96(7):2366-72

22. Xiaonan L, Carolyn FR, Joseph RP, Eric A, Barbara AR. Determination of Total Phenolic Content and Antioxidant Activity of Garlic (Allium sativum) and Elephant Garlic (Allium ampeloprasum) by Attenuated Total Reflectance Fourier Transformed Infrared Spectroscopy. J Agri Food Chem. 2011;59(10):5215-21.

Cite this article: Harmita, Suryadi H, Syarif M, Liksasa LD. Gas chromatography Analysis of Diallyl Disulphide and Diallyl Trisulphide and Antioxidant Activity in Black Garlic. Int. J. Pharm. Investigation. 2020;10(1):17-23. 